DOI: $10.19195 / 0524-4544.327 .4$

\author{
DOMINIKA CENDROWICZ \\ ORCID: 0000-0002-2358-7188 \\ Uniwersytet Wrocławski \\ dominika.cendrowicz@uwr.edu.pl
}

\title{
Zadania administracji publicznej z zakresu pomocy osobom bezdomnym w II Rzeczypospolitej
}

\begin{abstract}
Abstrakt: Niniejszy tekst wskazuje na prawne aspekty realizacji przez administrację publiczną zadań z zakresu pomocy osobom bezdomnym w II Rzeczypospolitej. Zjawisko bezdomności w okresie międzywojennym przybrało znaczne rozmiary i było następstwem nie tylko okresów zaborów i zniszczeń wojennych z lat 1914-1918, ale także problemów społecznych, które nawarstwiły się w okresie międzywojnia. Mimo wielu trudności państwo polskie podjęło z niemałym sukcesem trud stworzenia prawnego systemu opieki społecznej, który w swoich działaniach koncentrował się także na pomocy bezdomnym. Ustawą z dnia 16 sierpnia 1923 roku o opiece społecznej dokonano kategoryzacji osób bezdomnych. Opierała się ona na podziale bezdomnych na osoby bezdomne będące ofiarami wojen, które na pomoc ze strony państwa i jego administracji zasługiwały, oraz na osoby bezdomne określane mianem ,żebraków” i ,włóczęgów”, którym nie należała się pomoc i wobec których stosowano środki o charakterze represyjnym. System opieki społecznej oparto na zasadzie pomocniczości, zgodnie z którą podstawowym podmiotem zobowiązanym do jej udzielania, w tym pomocy bezdomnym, była gmina. Dostrzegano także, że do bezdomności prowadzić mogą złe warunki lokalowe. Ciągłość stworzonego w międzywojniu systemu opieki społecznej przerwał wybuch II wojny światowej, a następnie na długie lata został on zaprzepaszczony w okresie PRL, kiedy to problem bezdomności ukrywano, a administracja państwowa w ogóle się nim nie zajmowała.
\end{abstract}

Słowa kluczowe: administracja publiczna, samorząd terytorialny, zadania publiczne, międzywojnie, II Rzeczpospolita, bezdomność, osoby bezdomne, wykluczenie mieszkaniowe. 


\section{Uwagi wprowadzające}

„11 listopada 1918 roku spełnił się sen pokoleń Polaków — Państwo Polskie narodziło się na nowo. Po rozbiorach i 123 latach niewoli [...] wolna Polska powróciła na mapę świata"1. Wywalczona niepodległość przyniosła możliwość samodzielnego organizowania życia politycznego, gospodarczego i społecznego. Jej istotnym elementem stała się możliwość realizacji przez administrację publiczną zadań z zakresu ówczesnej opieki społecznej ${ }^{2}$. Zadania w tym obszarze okazały się jednymi z ważniejszych, jakie stanęły przed administracją ówczesnego państwa polskiego. Odrodzone państwo polskie borykało się z wieloma trudnościami natury społecznej i gospodarczej. W początkowym okresie funkcjonowania II Rzeczypospolitej ${ }^{3}$ nie było jednak szans na ustabilizowanie - w wielu przypadkach dramatycznej — sytuacji społecznej jej mieszkańców. Polska długo musiała czekać na ostateczne ustalenie swoich granic. Rezultatem działań wojennych, trzech powstań śląskich, powstania wielkopolskiego i wojny polsko-bolszewickiej były tysiące obywateli żyjących w skrajnym ubóstwie, którzy oczekiwali na pomoc ze strony nowo powstałego państwa ${ }^{4}$.

Problemami społecznymi, z którymi borykała się odrodzona po 123 latach niewoli Polska było nie tylko ubóstwo, ale także bezdomność i dramatyczna sytuacja mieszkaniowa panująca wśród uboższych warstw społeczeństwa. Problemy te potęgowały dokonane przez I wojnę światową spustoszenia, na skutek których wiele domów zostało zniszczonych, a ludność zmuszona została do ich odbudowy, co nie było zadaniem łatwym do realizacji. Aby wspomóc społeczeństwo w tych działaniach ustawą sejmową z dnia 28 lutego 1919 roku w przedmiocie zaopatrzenia ludności $\mathrm{w}$ drzewo budulcowe i opałowe ${ }^{5}$ oraz rozporządzeniem wykonawczym z dnia 14 marca 1919 roku o tym samym tytule ${ }^{6}$ postanowiono, że dla odbudowy zniszczonych przez działania wojenne domów mieszkalnych i zabudowań gospodarczych wraz z potrzebnymi ogrodzeniami wydawane będzie drzewo budulcowe i opałowe z lasów bez względu na porę roku (art. 1 i 2 u.z.l.d.).

Złą sytuację mieszkaniową w Polsce utrwalały nie tylko zniszczenia wojenne, ale także występujące $\mathrm{w}$ wielu regionach kraju zacofanie. W okresie II RP

1 Uchwała Sejmu Rzeczypospolitej Polskiej z dnia 25 maja 2017 r. w sprawie ustanowienia roku 2018 Rokiem Jubileuszu 100-lecia odzyskania przez Polskę Niepodległości.

2 P. Grata, Polityka spoleczna II Rzeczypospolitej wobec cyklu życia, „Problemy Polityki Społecznej" 2015, nr 1, s. 46.

3 Dalej także jako: II RP.

${ }^{4}$ Ł. Kabzińska, K. Kabziński, Wybrane aspekty zagrożonego dzieciństwa w dwudziestoleciu międzywojennym, „Warmińsko-Mazurski Kwartalnik Naukowy. Nauki Społeczne” 2012, nr 4, s. 12.

${ }^{5}$ Ustawa sejmowa z dnia 28 lutego 1919 r. w przedmiocie zaopatrzenia ludności w drzewo budulcowe i opałowe (Dziennik Praw Nr 20, poz. 229), dalej: u.z.l.d.

${ }^{6}$ Rozporządzenie z dnia 14 marca 1919 r. w przedmiocie zaopatrzenia ludności w drzewo budulcowe i opałowe (Monitor Polski Nr 63, poz. 1). 
wiele osób zamieszkiwało w przeludnionych lokalach ${ }^{7}$. Dość powszechne było zjawisko powstawania tzw. osiedli nędzy, na terenie których osoby ubogie stawiały nielegalne baraki mające zapewnić im schronienie. Do ich budowy używano drewna z okolicznych lasów, blachy, a nawet gliny ${ }^{8}$. W kraju wzrastała liczba osób bezdomnych ${ }^{9}$. Najliczniejsza grupa bezdomnych żyła w Warszawie. Według ówczesnych statystyk w Warszawie w 1932 roku przebywało aż 20 tys. osób bezdomnych ${ }^{10}$. W pozostałych miastach ówczesnej Polski — w zależności od okresu - liczba bezdomnych wahała się od kilkuset do kilku tysięcy (Poznań ponad 6 tys., Kraków - ok. 5 tys., Lwów - ok. 3 tys.) ${ }^{11}$. Szczególnie dramatyczne było położenie bezdomnych dzieci ${ }^{12}$, których sytuację opisał J. Kuchta w pracy pt. Dziecko włóczęga opublikowanej w 1936 roku $^{13}$ (trudna jest jednak do ustalenia dokładna liczba bezdomnych dzieci żyjących w II RP. M. Balcerek szacuje, że w każdym mieście wojewódzkim było od 1 do 2 tys. takich dzieci. W samej Warszawie liczbę dzieci bezdomnych szacowano na około tysiąc $\left.{ }^{14}\right)$.

Celem opracowania jest charakterystyka regulacji prawnych wyznaczających zadania administracji publicznej w sferze pomocy osobom bezdomnym w okresie międzywojennym, za których realizację w znacznej mierze odpowiedzialne były ówczesne jednostki samorządu terytorialnego, a w dalszej kolejności zwrócenie uwagi na uregulowania prawne z obszaru polityki mieszkaniowej w II Rzeczypospolitej.

7 Według spisu ludności w Warszawie mieszkań jednoizbowych było aż 75\%. Podaję za: W. Dobrzański, Opieka mieszkaniowa jako zadanie państwa i samorząów, „Praca i Opieka Społeczna" 1929, nr 1, s. 78.

${ }^{8}$ L. Linowski pisze, że w Gdyni w 1934 r. notowano baraki o wymiarach nawet $2 \times 2 \mathrm{~m}$. L. Linowski, Enklawy biedy w miastach Wielkiego Pomorza, [w:] Metamorfozy społeczne. Margines społeczny II Rzeczypospolitej, red. M. Rodak, Warszawa 2013, s. 317.

9 Określenie liczby osób bezdomnych w okresie międzywojennym jest zadaniem trudnym, jednak według I. Surmackiej na dzień 1 kwietnia 1934 r. liczba bezdomnych w Polsce wynosiła 19616 osób. I. Surmacka, Schroniska miejskie dla bezdomnych, „Praca i Opieka Społeczna” 1936, nr 3, s. 238.

10 Podaję za: M. Rodak, Zjawisko bezdomności w Drugiej Rzeczypospolitej (ze szczególnym uwzględnieniem Warszawy), [w:] Od kwestii robotniczej do nowoczesnej kwestii socjalnej. Studia z dziejów polskiej polityki społecznej XX i XXI wieku, red. P. Grata, Rzeszów 2013, s. 53.

11 M. Rodak, Bezdomność w międzywojennym Lublinie, „Rocznik Lubelski” 2015, nr 41, s. 161.

12 Pierwsze działania na rzecz bezdomnych dzieci i młodzieży zaczęto podejmować na podstawie uchwały Sejmu Ustawodawczego z 13 stycznia 1920 r., mocą której powołano Pogotowia Opiekuńcze, będące formą opieki tymczasowej dla dzieci porzuconych i bezdomnych, które miały być finansowane przez samorządy, instytucje społeczne i osoby prywatne, a także za pośrednictwem dotacji państwa.

13 J. Kuchta, Dziecko włóczęga. Z cyklu: Dzieci trudne do wychowania, Lwów 1936, s. 10-11.

14 M. Balcerek, Rozwój opieki nad dzieckiem w latach 1918-1939, Warszawa 1978, s. 207. 


\section{System opieki społecznej i administrowanie nim w II Rzeczypospolitej}

Opisane problemy społeczne II RP sprawiły, że jednym z ważniejszych zadań stojących przed odrodzonym państwem polskim stało się skoordynowanie działań na rzecz zapobiegania ubóstwu, w tym bezdomności, poprawy warunków mieszkaniowych społeczeństwa ${ }^{15}$ oraz uchwalenia przepisów dotyczących systemu opieki społecznej ${ }^{16}$. To ostatnie zadanie zostało zrealizowano z chwila uchwalenia Ustawy z dnia 16 sierpnia 1923 roku o opiece społecznej ${ }^{17}$, która przejęła na siebie ciężar organizacji instytucji opieki społecznej na terenie całego kraju, oraz wydania Rozporządzenia Prezydenta RP z dnia 6 marca 1928 roku o rozgraniczeniu obowiązków opiekuńczych związków komunalnych ${ }^{18}$. Zawarte w u.o.s. przepisy nie obowiązywały w sposób jednakowy na terytorium całej II RP. W województwach centralnych, wschodnich i południowych obowiązywały w całości, w województwie poznańskim i pomorskim obowiązywały w części ${ }^{19}$, na obszarze województwa śląskiego nie obowiązywały zaś w ogóle. Na terenie Górnego Śląska i Śląska Cieszyńskiego opiekę społeczną regulowały przepisy odrębne $^{20}$. Sytuacja ta była następstwem posiadanej przez Górny Śląsk autonomii w dziedzinie kształtowania regulacji prawnych z obszaru opieki społecznej, która wynikała z ustawy konstytucyjnej z dnia 15 lipca 1920 roku, zgodnie z którą zastrzeżono dla Sejmu Śląskiego ,ustawodawstwo o zaopatrzeniu ubogich i o zwalczaniu żebractwa i włóczęgostwa"21.

15 M. Brenk, Minęto 90 lat od uchwalenia ustawy o opiece społecznej, „Praca Socjalna” 2014, nr 1, s. 151.

16 R. Mędrzycki, Zadania administracji publicznej w zakresie przeciwdziałania bezdomności. Studium administracyjnoprawne, Warszawa 2016, s. 56. R. Mędrzycki podaje w tym zakresie przykłady następujących aktów prawnych: Ustawę z dnia 27 maja 1919 r. o tymczasowym zaopatrzeniu rodzin po wojskowych Wojska Polskiego (Dziennik Praw Nr 43, poz. 308), Ustawę z dnia 18 marca $1921 \mathrm{r}$ o zaopatrzeniu inwalidów wojennych i ich rodzin oraz o zaopatrzeniu rodzin po poległych i zmarłych lub zaginionych bez własnej winy, których śmierć, względnie zaginięcie pozostaje w związku przyczynowym ze służbą wojskową (Dz.U. Nr 32, poz. 195) oraz Rozporządzenie Ministra Zdrowia Publicznego z dnia 4 lipca 1921 r. w przedmiocie udostępnienia ubogiej ludności nabywania niektórych lekarstw (Dz.U. Nr 65, poz. 415).

17 Ustawa z dnia 16 sierpnia 1923 r. o opiece społecznej (Dz.U. Nr 92, poz. 726 ze zm.), dalej: o.p.s.

18 Rozporządzenie Prezydenta RP z dnia 6 marca 1928 r. o rozgraniczeniu obowiązków opiekuńczych związków komunalnych (Dz.U. Nr 26, poz. 232 ze zm.).

19 Zob. Rozporządzenie Ministra Opieki Społecznej z dnia 12 września 1938 r. o rozciągnięciu mocy art. 4 ustawy z dnia 16 sierpnia 1923 r. o opiece społecznej oraz o zniesieniu związków wspierania ubogich na obszarze województw poznańskiego i pomorskiego (Dz.U. Nr 74, poz. 523, 524 i 525).

20 M. Brenk, op. cit., s. 119.

21 Ustawa Konstytucyjna z dnia 15 lipca 1920 r. zawierająca statut organiczny Województwa Śląskiego (Dz.U. Nr 73, poz. 497). 
W II RP normowaną przepisami u.o.s. opiekę społeczną uznano za instytucję publiczną, a świadczenia z jej zakresu finansowane były z budżetu państwa ${ }^{22}$. Celem opieki społecznej było zaspokajanie ze środków publicznych niezbędnych potrzeb życiowych tych osób, które chwilowo nie mogły tego uczynić własną pracą lub własnymi środkami materialnymi, jak również zapobieganie tego rodzaju sytuacjom (art. 1 o.p.s.). Opieka społeczna objęła ochronę macierzyństwa, opiekę nad niemowlętami, dziećmi, młodzieżą, starcami, w tym nad bezdomnymi ofiarami wojen, walkę z żebractwem, a także sprawienie pogrzebu osobom zmarłym $(\text { art. } 2 \text { u.o.s. })^{23}$. Do jej działów w literaturze przedmiotu okresu międzywojennego zaliczano pomoc społeczną, opiekę właściwą, profilaktykę i ratownictwo ${ }^{24}$. Opieka społeczna polegała przede wszystkim na dostarczaniu niezbędnych środków, żywności, bielizny, podstawowej odzieży, pomieszczenia do mieszkania, narzędzi koniecznych w stopniu podstawowym do pracy zawodowej, pomocy higieniczno-sanitarnej, pomocy w przywróceniu utraconej lub podniesieniu zmniejszonej zdolności do pracy, pomocy w religijno-moralnym, fizycznym i umysłowym wychowaniu dzieci oraz na sprawieniu pogrzebu (art. 3 u.o.s.) $)^{25}$.

Na mocy przepisów u.o.s. ukształtował się w Polsce międzywojennej taki system opieki społecznej, w którym stanowiła ona obowiązek państwa ${ }^{26}$. Gminy wiejskie i miejskie zobowiązane zostały do wykonywania bezpośredniej opieki społecznej polegającej głównie na udzielaniu regulowanych u.o.s. świadczeń (art. 4 u.o.s.). Obowiązek udzielania opieki spoczywał na związkach komunalnych, w tym zwłaszcza na gminach będących podstawowymi jednostkami w układzie organizacji opiekuńczej ówczesnej administracji publicznej. Przypisanie zadań w zakresie opieki społecznej gminom wynikało z ich umiejscowienia w strukturze organizacyjnej międzywojennej administracji publicznej oraz obowiązujących w tamtym okresie konstytucyjnych uwarunkowań prawnych odnoszących się do funkcjonowania samorządu terytorialnego ${ }^{27}$. Podziału zadań z zakresu opieki społecznej między gminy, powiaty, województwa i państwo dokonano w art. 5

22 I. Sierpowska, Prawo pomocy społecznej, Warszawa 2011, s. 17.

23 W. Dawidowicz, Polskie prawo administracyjne, Warszawa 1980, s. 151.

24 I. Sendler, Zasady opieki społecznej, Warszawa 1935, s. 8, 58. Zob. także: J. Panejko, Administracja spoteczna, Wilno 1937.

25 J.S. Langrod, Praca i ubezpieczenie spoteczne, [w:] Zarys ustroju, postepowania i prawa administracyjnego $w$ Polsce, K.W. Kumaniecki, J.S. Langrod, S. Wachholz, Kraków-Warszawa 1939, s. 441.

${ }^{26}$ K. Chaczko, Polska w soczewce. Ewolucja oraz modernizacja systemu opieki i pomocy społecznej w perspektywie instytucjonalnej, „Rocznik Administracji Publicznej” 2016, nr 2, s. 353.

27 Zgodnie z Konstytucją z dnia 17 marca 1921 r. (Dz.U. Nr 44, poz. 267) Rzeczpospolita Polska opierała swój ustrój na zasadzie szerokiego samorządu terytorialnego, zgodnie zaś z Konstytucją z dnia 23 kwietnia 1935 r. (Dz.U. Nr 30, poz. 227) samorząd terytorialny stanowił część ówczesnej administracji państwowej. W tym zakresie gmina zaspokajała bieżące potrzeby społeczności gminnej poprzez wykonywanie zadań życia zbiorowego. Brała ponadto udział w wykonywaniu zadań administracji państwowej (art. 4 i 75). 
u.o.s. Zgodnie z ustępem 1 tego artykułu gminy wiejskie i miasta niewydzielone ze związku komunalnego powiatowego sprawowały zasadniczo opiekę pozazakładową. Obowiązek sprawowania opieki zakładowej przez gminy realizowany miał być w takim zakresie, na jaki zezwalały posiadane przez tę jednostkę samorządu terytorialnego środki finansowe. Obowiązek gminy ograniczał się jednak tylko do sprawowania opieki indywidualnej ${ }^{28}$. Gmina sprawowała opiekę na koszt własny nad obywatelami RP, o ile dany obywatel nabył prawo do trwałej opieki ze strony gminy przez co najmniej roczny w niej pobyt ${ }^{29}$. Jeśli nie nabył on takiego prawa, to gmina nie mogła mu co prawda odmówić pomocy, ale w takiej sytuacji miała prawo żądać zwrotu kosztów udzielonej mu pomocy od gminy właściwej, tj. zobowiązanej do udzielenia mu pomocy lub odesłać go do takiej gminy (art. 8 i 10 u.o.s.). Tak ukształtowany system opieki społecznej sprzyjał realizacji zasady pomocniczości w życiu publicznym ${ }^{30}$. W systemie tym

Państwo [sprawowało opiekę społeczną] [...] wtedy jedynie, gdy w stosunku do potrzebującego opieki pewne osoby fizyczne lub prawne na mocy przepisów czy innego tytułu prawnego nie są zobowiązane do pokrycia wydatków na niezbędne potrzeby życiowe ${ }^{31}$.

Rozwiązanie takie - zgodnie z którym to gminy w największym stopniu odpowiedzialne są za zaspokajanie potrzeb społeczeństwa w zakresie pomocy społecznej — widoczne jest także w rozwiązaniach prawnych zawartych w Ustawie z dnia 12 marca 2004 roku o pomocy społecznej ${ }^{32}$, która obecnie stanowi regulację prawną normującą zasady funkcjonowania systemu pomocy społecznej w Polsce.

\section{Charakter zadań administracji publicznej z zakresu pomocy osobom bezdomnym i ich miejsce w systemie opieki społecznej w II Rzeczypospolitej}

Ustawa o opiece społecznej z 1923 roku przez cały okres swojego obowiązywania nie definiowała pojęcia osoby bezdomnej ${ }^{33}$. W jej art. 2 lit. d i e dokonano jednak pewnej kategoryzacji bezdomnych na osoby bezdomne będące ofiarami wojen, włóczęgów i na żebraków. Zgodnie z tym podziałem osoby bezdomne bę-

28 Polityka społeczna państwa polskiego 1918-1935, Warszawa 1935, s. 298.

29 Prawo do opieki społecznej przysługiwało także cudzoziemcom, pod warunkiem jednak, że wynikało ono z zawartych przez Rzeczpospolitą umów międzynarodowych.

30 Zob. szerzej: I. Lipowicz, Gmina jako podmiot administracji świadczacej, „Ruch Prawniczy, Socjologiczny i Ekonomiczny" 2015, nr 3, s. 115-130.

31 Polityka spoleczna państwa polskiego..., s. 298.

32 Ustawa z dnia 12 marca 2004 r. o pomocy społecznej (Dz.U. z 2018 r. poz. 1580).

33 R. Mędrzycki, op. cit., s. 57. 
dące ofiarami wojen były to osoby, które trwale lub chwilowo własnymi środkami materialnymi lub własną pracą nie mogły zaspokoić swoich potrzeb życiowych i im należała się pomoc i opieka. Osobom określanym mianem żebraków i włóczęgów takiej pomocy nie udzielano, ponieważ zgodnie z art. 2 lit. e u.o.s. żebractwo i włóczęgostwo — na równi z alkoholizmem i nierządem — należało zwalczać ${ }^{34}$. W okresie międzywojennym uważano bowiem, że zarówno włóczęgostwo, jak i żebractwo wynikają z wyboru danego człowieka i że osoby będące włóczęgami i żebrakami zabierają środki do życia innym osobom, tj. takim, które stały się bezdomne nie z własnej winy ${ }^{35}$. Toteż celem zwalczania żebractwa i włóczęgostwa stosowano różnego rodzaju środki zapobiegawcze, poprawcze i karne ${ }^{36}$.

W sposób szczegółowy do kwestii żebractwa i włóczęgostwa odnosiło się Rozporządzenie Prezydenta RP z dnia 14 października 1927 roku o zwalczaniu żebractwa i włóczęgostwa ${ }^{37}$. Postanowienia analogiczne do zawartych w r.ż.i.w. zawierała Ustawa z dnia 28 czerwca 1939 roku o zwalczaniu żebractwa i włóczęgostwa $^{38}$ wydana dla województwa śląskiego. R.ż.i.w. wprowadziło środki zapobiegawcze i poprawcze wobec osób trudniących się żebractwem i włóczęgostwem ${ }^{39}$, osób niechętnych do podejmowania jakiegokolwiek zatrudnienia, a pobierających zasiłki z zakresu opieki społecznej, alkoholików, narkomanów i hazardzistów. Omawianym rozporządzeniem wprowadzono także definicję legalną żebraka i włóczęgi. Za żebraka uznano osobę, która zawodowo zajmowała się wypraszaniem dla siebie jałmużny (art. 2 r.ż.i.w.). Za włóczęgę uznano zaś osobę, która pozostawała bez pracy i jakichkolwiek środków do życia i stale zmieniała miejsce swojego pobytu w celu znalezienia zatrudnienia (art. 3 r.ż.i.w.).

Zgodnie z art. 5 r.ż.i.w. do walki z żebractwem i włóczęgostwem służyła określona infrastruktura organizacyjna. Należały do niej domy pracy dobrowolnej, przytułki i domy pracy przymusowej. Ich organizację określało Rozporządzenie Ministra Pracy i Opieki Społecznej z dnia 25 maja 1929 roku o organizacji przytułków, domów pracy dobrowolnej i domów pracy przymusowej ${ }^{40}$. W przytułkach

34 U.o.s. nie zaliczyła włóczęgów i żebraków do kręgu osób bezdomnych.

35 L. Stankiewicz, Zrozumieć bezdomność, Olsztyn 2002, s. 17.

36 Polityka spoleczna państwa polskiego..., s. 316-317.

37 Rozporządzenie Prezydenta Rzeczypospolitej z dnia 14 października 1927 r. o zwalczaniu żebractwa i włóczęgostwa (Dz.U. Nr 92, poz. 823), dalej: rozporządzenie o zwalczaniu żebractwa i włóczęgostwa, r.ż.i.w. Rozporządzenie to wydane zostało na podstawie art. 44 ust. 6 Konstytucji z dnia 17 marca 1921 r. i Ustawy z dnia 2 sierpnia 1926 r. o upoważnieniu Prezydenta RP do wydawania rozporządzeń z mocą ustawy (Dz.U. Nr 78, poz. 443).

38 Ustawa z dnia 28 czerwca 1939 r. o zwalczaniu żebractwa i włóczęgostwa (Dziennik Ustaw Śląskich $\mathrm{Nr} 22$, poz. 53).

$39 \mathrm{~W}$ odniesieniu do osób nieletnich do lat 17 środki w omawianym zakresie regulowały przepisy odrębne.

40 Rozporządzenie Ministra Pracy i Opieki Społecznej z dnia 25 maja 1929 r. o organizacji przytułków, domów pracy dobrowolnej i domów pracy przymusowej (Dz.U. z 1929 r. Nr 41, poz. 350), dalej: r.o.p.d. 
miały przebywać na mocy decyzji sądu osoby niezdolne do pracy (§ 1 r.o.p.d.). Natomiast pracujący na własne życzenie (żebracy, więźniowie po odbyciu kary, osoby po zwolnieniu $\mathrm{z}$ domu pracy przymusowej) mieli przebywać $\mathrm{w}$ domach pracy dobrowolnej, gdzie otrzymywali za swoją pracę wynagrodzenie ${ }^{41}$, którego wysokość zależała od wykonywanej pracy i od „umiejętności i zdolności pracującego”. Niezależnie od wynagrodzenia osoby przebywające w domach pracy dobrowolnej mogły otrzymywać premie. Zgodnie z § 15 r.o.p.d. wysokość wynagrodzenia w poszczególnych domach pracy dobrowolnej określana była zarządzeniem Ministra Pracy i Opieki Społecznej wydawanym na podstawie wniosku właściwego związku samorządowego i zaopiniowanym pozytywnie przez wojewodę (komisarza rządu m.st. Warszawy) (§ 15 ust. 2 r.o.p.d.). Do domów pracy dobrowolnej przyjmowani byli przez właściwe władze związku komunalnego żebracy i włóczędzy wykazujący się kartą zwolnienia $\mathrm{z}$ domu przymusowego (§ 14 r.o.p.d.). W domach pracy przymusowej przebywać miały przez okres od 3 do 6 miesięcy - a w wypadku ponownego zatrzymania nawet do 2 lat (art. 14 r.ż.i.w.) — osoby, które nie posiadały własnych środków utrzymania i skierowane zostały na pobyt do domu pracy przymusowej przez sąd, przy czym możliwe było zawieszenie lub skrócenie w odniesieniu do tych osób okresu ich pobytu w domu pracy przymusowej. Na dłuższy okres do domów pracy przymusowej kierowane były osoby, które, mając środki na utrzymanie, żebrały. Zgodnie z art. 25 r.ż.i.w. podlegały one karze od 6 miesięcy do 2 lat pobytu w domu pracy przymusowej (lub nawet do lat 5). Do domów pracy przymusowej osoby były kierowane wbrew ich woli, a więc z naruszeniem zasady ochrony i poszanowania wolności osobistej jednostki ${ }^{42}$.

Praca w domach pracy przymusowej trwała 8 godzin dziennie ${ }^{43}$. Osoby w nich przebywające dzielone były pomiędzy oddziały męskie i żeńskie. Osoby przebywające $\mathrm{w}$ oddziale dzielone były na sekcje, z których sekcja I obejmowała: internowanych w wieku od 17 do 21 lat, sekcja II obejmowała: internowanych za żebractwo i włóczęgostwo oraz na podstawie art. 4 i 35 ust. 2 r.ż.i.w., a sekcja III: karnych i niepoprawnych z sekcji II, dla których regulamin przebywania w domu pracy przymusowej miał być najsurowszy (§ 24 r.o.p.d.). Osobna sekcja tworzona była dla osób nieletnich ${ }^{44}$.

Za wykonanie przepisów r.ż.i.w. oraz r.o.p.d. odpowiedzialne były w większości władze samorządowe i to one głównie prowadziły zakłady opieki zamkniętej ${ }^{45}$.

41 P. Grata, op. cit., s. 56-57.

42 Aczkolwiek wciąż wbrew woli kieruje się osoby pozbawione zdolności do czynności prawnych na przymusowy pobyt w domach pomocy społecznej zgodnie z Ustawą z dnia 19 sierpnia 1994 r. o ochronie zdrowia psychicznego (tekst jedn. Dz.U. z 2018 r. poz. 1878).

43 D. Raś, O poprawie winowajców w więzieniach i zakładach dla nieletnich, Katowice 2006, S. $154-155$.

44 D. Raś, op. cit., s. 154-155.

45 P. Grata, op. cit., s. 56-57. 
Za prowadzenie przytułków odpowiedzialne były powiatowe związki komunalne i miasta wydzielone z powiatowego związku komunalnego. Obowiązek ten ciążył na nich w zależności od potrzeb występujących w zakresie tworzenia przytułków na terytorium ich właściwości (§ 1 r.o.p.d.). Domy pracy dobrowolnej obowiązek miały prowadzić wojewódzkie związki komunalne (także m.st. Warszawa). Obowiązek ten ciążył jednak także na związkach gminnych (§ 2 r.o.p.d.). Analogicznie kształtowała się sytuacja w odniesieniu do domów pracy przymusowej (§ 16 r.o.p.d.). Udział we wspieraniu opieki społecznej na terenie domów pracy dobrowolnej i przymusowej miało również wiele organizacji świeckich i kościelnych, które dostarczały ich mieszkańcom żywność, odzież, pomoc lekarską itp. Do ważniejszych organizacji wspierających opiekę społeczną w opisanym zakresie należały m.in.: Związek Pracy Obywatelskiej Kobiet, Związek Strzelecki, Obywatelski Komitet Pomocy Żydom, Caritas i Akcja Katolicka ${ }^{46}$.

Porównując dzisiejszy system pomocy osobom bezdomnym z tym funkcjonującym w okresie międzywojennym, zauważenia wymaga, że także dzisiaj podmiotem zobowiązanym do realizacji zadań na rzecz osób bezdomnych są przede wszystkim jednostki samorządu terytorialnego, a właściwie gminy (art. 17 ust. 1 pkt 3 u.p.s.), a także, że również obecnie działalność administracji publicznej na rzecz bezdomnych uzupełniana jest działalnością podmiotów niepublicznych. Międzywojenny system pomocy osobom bezdomnym w sposób zasadniczy różnił się jednak od obecnego. Po pierwsze tym, iż obecnie ugruntowany jest pogląd, zgodnie z którym udzielenie pomocy osobie bezdomnej nie jest uzależnione od tego, czy dana osoba znalazła się w stanie bezdomności z własnej winy. Po drugie, aktualnie obowiązuje zasada, zgodnie z którą istnieje obowiązek poszanowania godności osób bezdomnych (art. 30 Konstytucji Rzeczypospolitej Polskiej z dnia 2 kwietnia $1997 \mathrm{roku}^{47}$ ). Pomoc świadczona bezdomnym nie ma w obecnym stanie prawnym charakteru represyjnego, nie jest też udzielana wbrew woli osoby jej potrzebującej. Jej celem jest bądź doraźna pomoc znajdującym się w stanie bezdomności osobom, bądź pomoc $\mathrm{w}$ przezwyciężeniu tego stanu ${ }^{48}$. Po czwarte, bezdomność to dzisiaj podstawa uzasadniająca udzielanie wszystkich świadczeń z zakresu pomocy społecznej (art. 7 pkt 3 u.p.s.), a obowiązujące ustawodawstwo wprowadza definicję osoby bezdomnej na potrzeby ich udzielania daleko odbiegającą od tej z okresu międzywojennego (art. 6 pkt 8 u.p.s.).

46 A. Kamiński, Funkcje pedagogiki społecznej, Warszawa 1974, s. 77-78.

47 Konstytucja Rzeczypospolitej Polskiej z dnia 2 kwietnia 1997 r. (Dz.U. Nr 78, poz. 484 ze zm.).

48 Zadania administracji publicznej w tym zakresie określa przede wszystkim u.p.s. 


\section{Polityka mieszkaniowa jako narzędzie przeciwdziałania bezdomności w II Rzeczypospolitej}

Przeciwdziałaniu bezdomności w okresie międzywojennym służyć miały również postanowienia innych aktów prawnych aniżeli tylko u.o.s. oraz r.ż.i.w. Do przykładowych aktów prawnych mających sprzyjać prowadzeniu aktywnej polityki mieszkaniowej państwa, m.in. przeciwdziałającej zjawisku bezdomności wśród społeczeństwa, należały Ustawa tymczasowa z dnia 4 września 1918 roku o ochronie lokatorów ${ }^{49}$ oraz Dekret z dnia 16 stycznia 1919 roku o zapobieganiu brakowi mieszkań ${ }^{50}$, mocą którego na terenie byłego Królestwa Kongresowego za podstawę dla określania wysokości czynszu przyjęto normę obowiązującą w czerwcu 1914 roku (art. 1). Artykułem 9 dekretu o zapobieganiu brakowi mieszkań w miastach powyżej 30 tys. mieszkańców powołano urzędy mieszkaniowe do spraw najmu oraz działające przy nich urzędy rozjemcze. Na czele urzędów mieszkaniowych stał inspektor mieszkaniowy (art. 5 dekretu). W miastach liczących od 5 do 30 tys. mieszkańców funkcje urzędów mieszkaniowych sprawować mieli urzędnicy działający pod kierownictwem burmistrza, zaś w miastach poniżej 5 tys. mieszkańców i w gminach wiejskich nadzór wykonywać miały związki komunalne. Urzędy mieszkaniowe miały za zadanie gromadzić dane o istniejących w danej miejscowości stosunkach mieszkaniowych, zapobiegać brakowi mieszkań, prowadzić publiczne wykazy mieszkań nadających się na wynajem (art. 10 dekretu). Wykonywały one także zadania w zakresie zakazywania rozbiórki domów, których stan pozwalał na zamieszkiwanie, nakazywania podziału mieszkań na mniejsze i wynajęcia ich większej liczbie lokatorów, nakazywania odnajęcia części mieszkań w przypadku zajmowania ich przez zbyt małą liczbę osób, zajmowania niewynajętych przez okres dłuższy niż 3 miesiące lokali przez gminy i wynajmowanie ich za czynsz regulowany czy też nakazywania właścicielom zniszczonych nieruchomości mieszkalnych ich remontu ${ }^{51}$. Urzędy w swoich działaniach koncentrowały się także na walce z bezdomnością. Nadzór nad prawidłowym wykonywaniem powierzonych im zadań sprawował Minister Zdrowia Publicznego (art. 11 dekretu).

49 Ustawa tymczasowa z dnia 4 września 1918 r. o ochronie lokatorów (Dziennik Praw Nr 10, poz. 21).

50 Dekret z dnia 16 stycznia 1919 r. o zapobieganiu brakowi mieszkań (Dziennik Praw Nr 8, poz. 116), dalej: dekret.

51 P. Woźny, Międzywojenne i transformacyjne doświadczenia wspierania budownictwa na wynajem w Polsce - poszukiwanie modelu partnerstwa publiczno-prywatnego, „Problemy Rozwoju Miast i Wsi” 2004, nr 4, s. 41-42. 
Kwestii mieszkaniowej i problematyki ochrony praw lokatorów w II RP dotyczyły także Ustawa z dnia 28 czerwca 1919 roku o ochronie lokatorów ${ }^{52}$, Ustawa $\mathrm{z}$ dnia 18 grudnia 1920 roku o ochronie lokatorów ${ }^{53}$, Ustawa z dnia 11 kwietnia 1924 roku o ochronie lokatorów ${ }^{54}$ oraz dekret Prezydenta RP z dnia 14 listopada 1935 roku $^{55}$, którym nakazano obniżkę czynszów w okresie od 1 grudnia 1935 do 30 listopada 1937 roku $^{56}$ oraz zezwolono na swobodne kształtowanie czynszu w mieszkaniach nowo budowanych, dodatkowo upraszczając procedury eksmisyjne. Szczegółowe regulacje dotyczące ochrony lokatorów obowiązywały także na Górnym Śląsku w postaci Ustawy z dnia 16 grudnia 1926 roku w sprawie ochrony lokatorów ${ }^{57}$.

W ślad za W. Federczykiem można stwierdzić, że wszystkie z wymienionych regulacji prawnych odnoszących się do polityki mieszkaniowej i ochrony lokatorów w okresie II RP obejmowały następujący katalog spraw, zgodnie z którym:

1. przepisy o ochronie lokatorów stanowiły normy prawne o charakterze lex specialis wobec przepisów prawa cywilnego regulujących najem;

2. uregulowano sposób określania wysokości czynszów i dokonywania ich podwyżek;

3. ustanowiono zakaz wypowiadania umów najmu poza sytuacjami, w których następowała zwłoka w zapłacie czynszu, zakłócanie porządku domowego oraz posiadanie tytułu prawnego do innego lokalu;

4. powołano w miejscowościach liczących powyżej 20 tys. mieszkańców urzędy rozjemcze do rozstrzygania sporów dotyczących najmu i opłat za lokal ${ }^{58}$.

W. Federczyk wskazuje także, że na mocy omawianych przepisów uregulowano kwestię uprawnienia do kontynuowania najmu po śmierci najemcy w przypadku wstępnych, zstępnych, współmałżonka i rodzeństwa zamieszkałego w lokalu stale do chwili śmierci najemcy oraz objęto regulacją prawną najem lokali użytkowych ${ }^{59}$.

Celem prowadzenia skutecznej polityki mieszkaniowej w okresie II RP wydana została także Ustawa z dnia 1 sierpnia 1919 roku o Państwowym Fundu-

52 Ustawa z dnia 28 czerwca 1919 r. o ochronie lokatorów (Dziennik Praw Nr 52, poz. 335).

53 Ustawa z dnia 18 grudnia 1920 r. o ochronie lokatorów (Dz.U. z 1921 r. Nr 4, poz. 19).

54 Ustawa z dnia 11 kwietnia 1924 r. o ochronie lokatorów (Dz.U. Nr 39, poz. 406).

55 Dekret Prezydenta Rzeczypospolitej z dnia 14 listopada 1935 r. w sprawie obniżenia komornego oraz zmiany ustawy o ochronie lokatorów (Dz.U. Nr 82, poz. 503 i 504).

56 Art. 1 Dekretu Prezydenta Rzeczypospolitej z dnia 14 listopada 1935 r. w sprawie obniżenia komornego oraz zmiany ustawy o ochronie lokatorów.

57 Ustawa z dnia 16 grudnia 1926 r. w sprawie ochrony lokatorów (Dziennik Ustaw Śląskich Nr 29, poz. 54).

58 W. Federczyk, Wybrane problemy ochrony praw lokatora i gospodarki mieszkaniowej gmin w Polsce, ,Samorząd Terytorialny” 2008, nr 4, s. 31. Zob. także: Rozdział IV Ustawy z dnia 11 kwietnia 1924 r. o ochronie lokatorów zatytułowany „Urzędy rozjemcze do spraw najmu” oraz „Gazeta Urzędowa Starostwa Ostrołęckiego” 1919, R. 2, nr 19 (z dnia 20 września).

59 W. Federczyk, op. cit., s. 31. 
szu Mieszkaniowym ${ }^{60}$, a w dniu 26 września 1922 roku uchwalona została przez parlament ustawa w przedmiocie rozbudowy miast ${ }^{61}$, która zobowiązała gminy miejskie, w których „ruch budowlany jest w zastoju lub niedostateczny i w których istnieje brak mieszkań" do podejmowania działań mających na celu poprawę tej sytuacji ${ }^{62}$. Odnośnie zaś do u.P.F.M., to jej mocą został utworzony specjalny fundusz, którego celem funkcjonowania miało być ułatwienie budowy domów z małymi i tanimi mieszkaniami przeznaczonymi dla osób biednych i ubogich (art. 1 u.P.F.M.). Za małe, tanie mieszkania, zgodnie z art. 8 u.P.F.M., uznano mieszkania, których powierzchnia, nie uwzględniając pomieszczeń takich, jak m.in. przedpokój, kuchnia czy łazienka, nie wynosiła więcej niż $100 \mathrm{~m}^{2}$ i z których czynsz miał być pobierany w takiej wysokości, żeby właściciel domu po potrąceniu z ogólnej sumy czynszowej wydatków na zapłacenie procentów od pożyczonego kapitału, na opłacenie rat umarzających pożyczkę i na utrzymanie domu w należytym porządku, mógł otrzymać od własnego kapitału wydanego na budowę domu lub kupno placu, nie więcej niż $7 \%$.

Zarząd nad funduszem powierzono Komisji Państwowego Funduszu Mieszkaniowego, powołanej przy Ministerstwie Zdrowia Publicznego (art. 2 u.P.F.M.). Przyznawała ona pożyczki zarządom komunalnym na:

a) zakup terenów, materiałów budowlanych (lub ich wytworzenie) oraz na budowę domów z „małymi, tanimi mieszkaniami higienicznymi” dla ludności niezamożnej, w szczególności dla inwalidów wojennych, dla wdów i sierot po poległych wojskowych, oraz dla niezamożnych, wielodzietnych rodzin robotniczych i urzędniczych;

b) pomoc kooperatywom mieszkaniowym, organizacjom społecznym, instytucjom i osobom prywatnym na zakup terenów pod budowę i na budowę „małych, tanich mieszkań higienicznych".

Komisja Państwowego Funduszu Mieszkaniowego udzielała także poręczenia zarządom komunalnym, instytucjom państwowym, kooperatywom mieszkaniowym i organizacjom społecznym na pożyczki zaciągane $\mathrm{w}$ instytucjach kredytowych lub ubezpieczeniowych i u osób prywatnych ${ }^{64}$.

Ze względu na ustrojowy i gospodarczy model II RP działania władz publicznych skupiały się na ochronie lokatorów i ich praw, a nie na bezpośrednim

60 Ustawa z dnia 1 sierpnia 1919 r. w przedmiocie utworzenia Państwowego Funduszu Mieszkaniowego (Dz.U. Nr 72, poz. 424), dalej: u.P.F.M.

61 Ustawa z dnia 26 września 1922 r. w przedmiocie rozbudowy miast (Dz.U. Nr 89, poz. 811).

62 A. Witkowski, Podatkowe dochody funduszy celowych na rzecz rozbudowy miast $w$ Polsce międzywojennej, „Administracja: Teoria, Dydaktyka, Praktyka” 2011, nr 4, s. 219.

63 Czynsz i każdą jego zmianę co do zasady zatwierdzała Komisja Państwowego Funduszu Mieszkaniowego.

64 A. Witkowski, op. cit., s. 218. 
zapewnieniu mieszkań osobom ich nieposiadającym. Polityka mieszkaniowa prowadzona w okresie II RP nie stanowiła wobec tego rzeczywistego narzędzia pomocy osobom bezdomnym w przezwyciężaniu przez nie stanu bezdomności.

\section{Konkluzje}

Międzywojenny system opieki społecznej, mimo że budowany praktycznie od podstaw i napotykający na wiele barier, z biegiem czasu stał się nowoczesnym jak na tamte czasy systemem działań władz publicznych, w tym samorządowych, dodatkowo respektującym zasadę pomocniczości, ukierunkowanym na rozwiązywanie licznych kwestii społecznych występujących w II RP65, wśród których bezdomność zajmowała ważne i niechlubne miejsce. Odnośnie do przeciwdziałania bezdomności, zauważenia wymaga, że działania ówczesnej administracji publicznej nie przynosiły jednak większego efektu. Dokonana przepisami r.ż.i.w. kategoryzacja bezdomnych i wyłączenie przez u.o.s. żebraków i włóczęgów z kategorii osób zasługujących na pomoc, w tym ustanowienie wobec nich środków represyjnych, determinowały sposoby realizacji zadań na rzecz osób bezdomnych przez ówczesną administrację publiczną ${ }^{66}$. Występujące w okresie II RP nastawienie do bezdomnych było negatywne, nierzadko jednostronne i brakowało w nim wiedzy o skomplikowanych przyczynach bezdomności i o wielości dróg, które do niej prowadzą ${ }^{67}$. Przede wszystkim uważano, że żebracy i włóczędzy sami winni są swojej sytuacji i że stanowią oni margines społeczny. Podejście to znajdowało

65 P. Grata, op. cit., s. 46.

66 Ówczesne postrzeganie tej grupy osób odzwierciedlają wyrażane w ówczesnej literaturze fachowej głosy na temat osób bezdomnych i bezdomności. W literaturze okresu międzywojennego uznawano, że „Bezdomność jest zjawiskiem skomplikowanym, trudnym do sklasyfikowania, a tym bardziej rozwiązania, powstaje bowiem, jako skutek wielu różnorodnych przyczyn. W największym odsetku przypadków, bezdomność powodują: złe warunki ekonomiczne (kryzys, bezrobocie, nędza), kataklizmy i przewroty dziejowe (wojna, rewolucja) oraz klęski przyrody (powodzie, pożary, trzęsienie ziemi itp.). Niezależnie jednak od tych przyczyn uchwytnych, których usunięcie uwarunkowane jest jedynie środkami materialnymi, istnieją przyczyny nieuchwytne i na zewnątrz niedostrzegalne, a jednak bardzo istotne, bo mające swe źródło w swoistych właściwościach natury ludzkiej. Aspołeczne czy antyspołeczne nastawienie człowieka do otoczenia, zaburzenia chorobowe, predyspozycje psychiczne, nałogi itp. oto przyczyny, które stwarzają w człowieku kompleks bezdomności, powodując w konsekwencji usunięcie go z orbity naturalnej egzystencji, czyniąc go bezdomnym. Walka z tą formą bezdomności jest niemal beznadziejna i z domeny społeczno-ekonomicznej wkracza w domenę lecznictwa”. Podaję za: H. Jawidzyk, Sprawa mieszkaniowa, „Opiekun Społeczny” 1938, nr 6, s. 40.

67 Zob. np. A. Ostrowski, Walka ludności wiejskiej z żebractwem w Polsce. Referat wygłoszony na I Ogólnopolskim Zjeździe Przeciwżebraczym w Poznaniu, który odbył się w dniach 24-26 lutego 1937 r., Materiały z I Ogólnopolskiego Zjazdu Przeciwżebraczego w Poznaniu, Poznań 1937. Tekst referatu wydrukowano w Rolniczej Drukarni i Księgarni Nakładowej. 
odzwierciedlenie w tworzonym prawie i skutkowało takim a nie innym systemem norm prawnych regulujących pomoc osobom bezdomnym. W działaniach ówczesnych władz publicznych na rzecz przeciwdziałania żebractwu i włóczęgostwu brakowało poszanowania godności tej grupy osób ${ }^{68}$, tak charakterystycznego dla dzisiejszego systemu pomocy społecznej.

Realizację zadań administracji publicznej w omawianym zakresie, a także z obszaru polityki mieszkaniowej, przerwał wybuch II wojny światowej, a następnie zmiana systemu ustrojowego państwa. Czynniki te spowodowały zmiany w zakresie systemu opieki społecznej po 1945 roku. Mimo że obowiązywanie u.o.s. zostało formalnie potwierdzone Dekretem z dnia 22 października $1947 \mathrm{roku}$ w sprawie mocy obowiązującej niektórych przepisów ustawodawstwa z zakresu opieki społecznej ${ }^{69}$, to faktycznie ustanowiony w międzywojniu system opieki adresowanej do bezdomnych stracił na znaczeniu. Uważano nawet, iż u.o.s. przestała obowiązywać na mocy tzw. desuetudo ${ }^{70}$. Na skutek likwidacji samorządu terytorialnego w 1950 roku obowiązki gmin wiejskich i miejskich oraz powiatowych związków samorządowych z zakresu opieki społecznej przeszły na organy administracji terytorialnej stopnia podstawowego, a zadania wojewódzkich związków samorządowych przejęły organy administracji terytorialnej stopnia wojewódzkie$\mathrm{go}^{71}$. Rozwój opieki społecznej był hamowany, nastąpił odwrót od realizowanego w międzywojniu pluralistycznego modelu opieki społecznej, a w 1960 roku nastąpiła likwidacja Urzędu Ministra Pracy i Opieki Społecznej i podporządkowanie opieki społecznej utworzonemu wówczas Ministerstwu Zdrowia i Opieki Społecz$n j^{72}$. Potwierdzeniem przeobrażeń, jakie nastąpiły w systemie opieki społecznej po 1945 roku i realizowanych przez administrację publiczną zadań z jej zakresu, była zwłaszcza zasada „od każdego według jego zdolności, każdemu według jego pracy" wprowadzona przez art. 14 Konstytucji Polskiej Rzeczypospolitej Ludowej $\mathrm{z}$ dnia 22 lipca 1952 roku $^{73}$. Wskazane zmiany na wiele lat zaprzepaściły osiągnięcia międzywojennego systemu opieki społecznej. W wielu obszarach przerwały także ciągłość zadań realizowanych przez administrację publiczną na rzecz osób bezdomnych w okresie II RP.

68 Szerzej: M. Granat, Godność człowieka a problem bezdomności, [w:] Bezdomność. Problemy prawne, innowacyjne rozwiąania, red. I. Lipowicz, Warszawa 2016, s. 14-28.

69 Dekret z dnia 22 października 1947 r. w sprawie mocy obowiązującej niektórych przepisów ustawodawstwa z zakresu opieki społecznej (Dz.U. Nr 65, poz. 389).

${ }^{70}$ Moc obowiązującą tej ustawy potwierdził jednak Naczelny Sąd Administracyjny w wyroku z dnia 27 kwietnia 1981 r., SA 767/81, CBOSA.

71 Na mocy art. 32 Ustawy z dnia 20 marca 1950 r. o terenowych organach jednolitej władzy państwowej (Dz.U. Nr 14, poz. 30) zniesione zostały związki samorządu terytorialnego, a ich majątek stał się z mocy prawa majątkiem państwa.

72 Zob. Ustawa z dnia 13 kwietnia 1960 r. o utworzeniu Komitetu Pracy i Płac oraz o zmianie właściwości w dziedzinie ubezpieczeń społecznych, rent, zaopatrzeń i opieki społecznej (Dz.U. Nr 20, poz. 119).

${ }^{73}$ Konstytucja Polskiej Rzeczypospolitej Ludowej z dnia 22 lipca 1952 r. (Dz.U. Nr 33, poz. 232). 


\section{Bibliografia}

Balcerek M., Rozwój opieki nad dzieckiem w latach 1918-1939, Warszawa 1978.

Brenk M., Minęło 90 lat od uchwalenia ustawy o opiece społecznej, „Praca Socjalna” 2014, nr 1.

Chaczko K., Polska w soczewce. Ewolucja oraz modernizacja systemu opieki pomocy społecznej w perspektywie instytucjonalnej, „Rocznik Administracji Publicznej” 2016, nr 2.

Dawidowicz W., Polskie prawo administracyjne, Warszawa 1980.

Dobrzański W., Opieka mieszkaniowa jako zadanie państwa i samorząów, „Praca i Opieka Społeczna" 1929, nr 1.

Federczyk W., Wybrane problemy ochrony praw lokatora i gospodarki mieszkaniowej gmin w Polsce, „Samorząd Terytorialny” 2008, nr 4.

Granat M., Godność człowieka a problem bezdomności, [w:] Bezdomność. Problemy prawne, innowacyjne rozwiazania, red. I. Lipowicz, Warszawa 2016.

Grata P., Polityka społeczna II Rzeczypospolitej wobec cyklu życia, „Problemy Polityki Społecznej" 2015, nr 1.

Jawidzyk A., Sprawa mieszkaniowa, „Opiekun Społeczny” 1938, nr 6.

Kabzińska Ł., Kabziński K., Wybrane aspekty zagrożonego dzieciństwa w dwudziestoleciu międzywojennym, „Warmińsko-Mazurski Kwartalnik Naukowy. Nauki Społeczne” 2012, nr 4.

Kamiński A., Funkcje pedagogiki społecznej, Warszawa 1974.

Kuchta J., Dziecko włóczęga. Z cyklu: Dzieci trudne do wychowania, Lwów 1936.

Langrod J.S., Praca i ubezpieczenie społeczne, [w:] K.W. Kumaniecki, J.S. Langrod, S. Wachholz, Zarys ustroju, postępowania i prawa administracyjnego w Polsce, Kraków-Warszawa 1939.

Linowski L., Enklawy biedy w miastach Wielkiego Pomorza, [w:] Metamorfozy społeczne. Margines społeczny II Rzeczypospolitej, red. M. Rodak, Warszawa 2013.

Lipowicz I, Gmina jako podmiot administracji świadczacej, „Ruch Prawniczy, Socjologiczny i Ekonomiczny" 2015, nr 3.

Mędrzycki R., Zadania administracji publicznej w zakresie przeciwdziałania bezdomności. Studium administracyjnoprawne, Warszawa 2016.

Panejko J., Administracja spoleczna, Wilno 1937.

Raś D., O poprawie winowajców w więzieniach i zakładach dla nieletnich, Katowice 2006.

Rodak M., Bezdomność w międzywojennym Lublinie, „Rocznik Lubelski” 2015, nr 41.

Rodak M., Zjawisko bezdomności w Drugiej Rzeczypospolitej (ze szczególnym uwzględnieniem Warszawy), [w:] Od kwestii robotniczej do nowoczesnej kwestii socjalnej. Studia z dziejów polskiej polityki społecznej XX i XXI wieku, red. P. Grata, Rzeszów 2013.

Sendler I., Zasady opieki społecznej, Warszawa 1935.

Sierpowska I., Prawo pomocy społecznej, Warszawa 2011.

Surmacka I., Schroniska miejskie dla bezdomnych, „Praca i Opieka Społeczna” 1936, nr 3.

Stankiewicz L., Zrozumieć bezdomność, Olsztyn 2002.

Witkowski A., Podatkowe dochody funduszy celowych na rzecz rozbudowy miast $w$ Polsce międzywojennej, „Administracja: Teoria, Dydaktyka, Praktyka” 2011, nr 4.

Woźny P., Międzywojenne i transformacyjne doświadczenia wspierania budownictwa na wynajem w Polsce - poszukiwanie modelu partnerstwa publiczno-prywatnego, „Problemy Rozwoju Miast i Wsi” 2004, nr 4. 


\title{
Tasks of public administration in the field of providing help to homeless people in the Second Polish Republic
}

\author{
Summary
}

The article describes the legal aspects of providing help to homeless people by public administration in the Second Polish Republic. Homelessness in the interwar period in Poland had taken on particularly worrying dimensions and was not only the result of war damages from the years 1914-1918, but also of many social problems which had been accumulating throughout the whole interwar period. Despite all these difficulties, the Polish state made a great effort in order to establish the legal system of social assistance which focused on helping the homeless. However, the Social Assistance Act of August 16, 1923, differentiated homeless people into two categories. In the first category were homeless who deserved help from the state and its administration. In the second group were those named "beggars" and "vagrants" who, as it was thought, didn't deserve help and in respect of whom repressive measures were taken. Despite many shortcomings of the social assistance system of that time, it was based on the principle of subsidiarity which is worth mentioning here. The basic subject obliged to provide help to the homeless in the Second Republic of Poland was a commune. It was also noticed then that poor housing conditions result in homelessness. The continuity of the system of social assistance from the interwar period was interrupted when World War II broke out. It was then thwarted in the People's Republic of Poland which was a time when the problem of homeless was hidden and state administration was not concerned with it.

Keywords: public administration, local self-government, public tasks, interwar period, Second Polish Republic, homelessness, homeless people, housing exclusion. 